\title{
Factors Affecting the Cropping Patterns in Hills and Plains of the Central Development Region
}

\author{
Raj Man Shrestha \\ Department of Statistics, Tri-Chandra Multiple Campus \\ Tribhuvan University, Nepal
}

\begin{abstract}
Due to expansion of urbanization, introduction of advanced technology in the agriculture systems and low returns in traditional farming systems, farmers of the Central Development Region of Nepal were compelled to change the traditional farming systems to modern systems. The present study aims to find out the factors that affected the changes in cropping patterns in hills and plains of this region and develop statistical models to explain these changes. Primary data were collected from key persons residing in the villages of four districts (Kavrepalanchowk, Bhaktapur, Chitawan and Parsa) Region under multistage sampling technique. Causal factors such as plot size, distance from market centre, family size, profit and market opportunities had significant effects while other two factors, education and irrigation had insignificant effects on the changes in cropping patterns in the region. Plot size and distance had negative effects on change in cropping patterns from modern to traditional. Profit factor had significant effect on change in cropping patterns in Terai, whereas family size had significant effect on change in the hills of the Central Development Region.
\end{abstract}

Key words: farming systems, multistage sampling, modern crops, traditional crops

\section{Introduction}

Agriculture is the main economic activity of Nepalese farmers in which $67 \%$ (CBS 2001) of the total population have been involved. It has contributed $39 \%$ of the total in national GDP. Due to expansion of urbanization, introduction of advanced technology in agriculture and low returns from traditional farming systems, farmers were compelled to switch over to professions other than agriculture (Shrestha 2006). Further, farmers those who were still engaged in agriculture had to change their traditional farming systems to modern systems for their existence. As in other developing countries, Nepal also has been following the problem of migration of people from rural to urban centers. The problem exerted a heavy pressure on the fertile land at the peripherals of city areas and caused changes in cropping systems in these areas (Ranjit 1983). The present study aims to find out the factors that affected the changes in cropping patterns in hills and plains of the Central Development Region of Nepal, and develop statistical models to explain these changes.

\section{Methodology}

A survey was conducted in four districts (Kavrepalanchowk, Bhaktapur, Chitawan and Parsa) of the Central Development Region. Altogether 198 samples ( 96 from hill and 102 from plain regions) of the key informants (Mathema \& Van Der Veen. 1978) under multistage sampling technique (Cochran 1977) were interviewed for getting information regarding this study. Logistic regression (Garson 2009) was applied to analyze the collected information.

\section{Logistic Regression Analysis}

Logistic regression analysis was done under the consideration of 'types of crops'(y) as the dichotomous criterion variable with the predictors plot size $\left(\mathrm{x}_{1}\right)$, distance $\left(\mathrm{x}_{2}\right)$, irrigation $\left(\mathrm{x}_{3}\right)$, profit $\left(\mathrm{x}_{4}\right)$, family size $\left(\mathrm{x}_{5}\right)$, education $\left(\mathrm{x}_{6}\right)$ and market $\left(\mathrm{x}_{7}\right)$, i.e. $\mathrm{y}$ is the function of $\mathrm{x}_{\mathrm{i}}$. Let $p=$ probability of success $=$ probability that the crop is modern $=\mathrm{P}($ modern $)=$ 
$\mathrm{P}(\mathrm{y}=1)$ and $1-p=$ probability of failure $=\mathrm{P}(\mathrm{y}=0)=$ $\mathrm{P}$ (traditional). The model is given by

$\ln \left(\frac{\hat{p}}{1-\hat{p}}\right)=b_{0}+b_{1} x_{1}+b_{2} x_{2}+b_{3} x_{3}+b_{4} x_{4}+b_{5} x_{5}+b_{6} x_{6}+b_{7} x_{7}$ where $b_{i}(\mathrm{i}=1,2 \ldots 7)$ are the parameters to be estimated. $\ln \left(\frac{\hat{p}}{1-\hat{p}}\right)$ is log odds of favoring "modern crop" compared to "traditional crop". The decision will be taken under the given predictors by this model. $\hat{p}$ is the predicted probability that the event (crop) is modern $(y=1)$ and is the predicted probability that the event (crop) is traditional ( $\mathrm{y}=0)$.

Input variables in the model as

$$
\begin{aligned}
\mathrm{y} & =1, \text { if crop type is "modern" } \\
& =0, \text { if crop type is "traditional" }
\end{aligned}
$$

Variables $\mathrm{x}_{1}=$ area of plot measured in hector, $\mathrm{x}_{2}=$ distance of the plot from market centre, $x_{3}=$ area of the plot under irrigation (irrigation) measured in hector and $\mathrm{x}_{5}=$ family size were continuous variables and $\mathrm{x}_{4}, \mathrm{x}_{6}$ and $\mathrm{x}_{7}$ were inputted as dummy and categorical variables.

$$
\begin{aligned}
& \mathrm{x}_{4}=1 \text {, if profit is "yes" } \\
& =0 \text {, otherwise } \\
& \text { and } \mathrm{x}_{6}=1 \text {, if education is "illiterate" (illit) }
\end{aligned}
$$

$=2$, if education is "primary" (prim)

$=3$, if education is "under SLC" (slc)

$=4$, if education is "above SLC" (ab_slc) Similarly,

$$
\mathrm{x}_{7}=1 \text {, if market is " } \operatorname{good} \text { " }(\mathrm{G})
$$$$
=2 \text {, if market is "so so" ( } \mathrm{S} \text { ) }
$$$$
=3 \text {, if market is "bad" (B) }
$$

The comparative study was done under two types of crops - modern and traditional for hills and plains (Terai region) of the Central developing Region. Using the statistical package SPSS version 10.0, the collected data were analyzed under logistic regression and the results have been interpreted in the forthcoming paragraphs.

\section{Results and Discussion}

\section{Effects of Factors on Cropping Patterns in the Hills}

First of all, the collected data of hill region were fitted by logistic regression model. Independent variables entered in the models were plot size $\left(\mathrm{x}_{1}\right)$, distance $\left(\mathrm{x}_{2}\right)$, irrigation $\left(\mathrm{x}_{3}\right)$, profit $\left(\mathrm{x}_{4}\right)$, family size $\left(\mathrm{x}_{5}\right)$, education $\left(\mathrm{x}_{6}\right)$ and market $\left(\mathrm{x}_{7}\right)$. Using stepwise (forward Wald)(SPSS 1999) logistic regression analysis besides the variables such as plot size $\left(\mathrm{x}_{1}\right)$, distance $\left(\mathrm{x}_{2}\right)$ and family size $\left(\mathrm{x}_{5}\right)$, other variables were not accepted. Table 1 shows the descriptive statistics of variables under consideration

\begin{tabular}{|c|c|c|c|c|c|c|c|c|c|}
\hline & \multirow{2}{*}{ Predictors } & \multirow{2}{*}{$\mathrm{b}$} & \multirow{2}{*}{ S.E. } & \multirow{2}{*}{ Wald } & \multirow{2}{*}{$\mathrm{df}$} & \multirow{2}{*}{ Sig. } & \multirow{2}{*}{$\operatorname{Exp}(b)$} & \multicolumn{2}{|c|}{ 95\% C.I. for $\operatorname{Exp}(\mathrm{b})$} \\
\hline & & & & & & & & Lower & Upper \\
\hline Step 3 & $\begin{array}{l}\text { Plot size }\left(\mathrm{x}_{1}\right) \\
\text { Distance }\left(\mathrm{x}_{2}\right) \\
\text { Family size }\left(\mathrm{x}_{5}\right) \\
\text { Constant }\end{array}$ & $\begin{array}{l}-7.513 \\
-1.056 \\
.533 \\
1.893\end{array}$ & $\begin{array}{l}2.774 \\
.294 \\
.218 \\
1.042\end{array}$ & $\begin{array}{l}7.336 \\
12.858 \\
5.995 \\
3.302\end{array}$ & $\begin{array}{l}1 \\
1 \\
1 \\
1\end{array}$ & $\begin{array}{l}.007 \\
.000 \\
.014 \\
.069\end{array}$ & $\begin{array}{l}.001 \\
.348 \\
1.704 \\
6.642\end{array}$ & $\begin{array}{l}.000 \\
.195 \\
1.112\end{array}$ & $\begin{array}{l}.125 \\
.620 \\
2.610\end{array}$ \\
\hline
\end{tabular}
in hill region.

Table 1. Descriptive statistics of the variables for hill region.

\begin{tabular}{l|c|c|c|c|c}
\hline & $\mathrm{N}$ & Minimum & Maximum & Mean & Variance \\
\hline Crop variety $(\mathrm{y})$ & 96 & 0.000 & 1.000 & & \\
Plot size $\left(\mathrm{x}_{1}\right)$ & 96 & 0.000 & 0.700 & 0.182 & 0.037 \\
Distance $\left(\mathrm{x}_{2}\right)$ & 96 & 0.150 & 7.000 & 2.489 & 3.361 \\
Irrigation $\left(\mathrm{x}_{3}\right)$ & 96 & 0.000 & 0.700 & 0.098 & 0.024 \\
Profit $\left(\mathrm{x}_{4}\right)$ & 96 & 0.000 & 1.000 & & 3.400 \\
Family size $\left(\mathrm{x}_{5}\right)$ & 96 & 2.000 & 9.000 & 4.900 & \\
\hline Total $\mathrm{N}$ & 96 & & & & \\
\hline
\end{tabular}

The estimated values of parameters ( $b$ 's) of the independent variables (predictors) are given in the Table 2.

Table 2. Variables (factors) and estimated parameters with significant values of the model for hill region

a Variable(s) entered on step 1: Distance

b Variable(s) entered on step 2: Plot size

c Variable(s) entered on step 3: Family size. 
Raj Man Shrestha/Factors Affecting the.....

From the results given in the Table 2, logistic regression with following parameters (coefficients) was fitted for hill region of Central Development Region.

$\ln \left(\frac{\hat{p}}{1-\hat{p}}\right)=1.893-7.513 x_{1}-1.056 x_{2}+0.533 x_{5}$

Table 3. Correlation Matrix where, $\mathrm{x}_{1}=$ Plot size, $\mathrm{x}_{2}=$ Distance and $\mathrm{x}_{5}=$ Family size. The model was fitted well and was verified by the Hosmer and Lemeshow (SPSS 1999) chi-square value of 10.403 with 8 degrees of freedom that was insignificant $(\mathrm{p}=0.24)$ and also obtaining a high $\mathrm{R}^{2}$ value of 0.737 (Nagelkerke $\mathrm{R}^{2}$ ) as well. Table 3 shows multicolinearity between the independent variables.

\begin{tabular}{cl|l|l|c|c}
\hline & & Plot size & Distance & Family size \\
\hline Step 3 & Constant & 1.000 & .178 & -.479 & -.653 \\
& Plot size & 0.178 & 1.000 & -1.95 & -.263 \\
& Distance & -0.479 & -.195 & 1.000 & -.155 \\
& Family size & -0.653 & -.263 & -.155 & 1.000 \\
\hline
\end{tabular}

Note : VIF is around 1 in all cases.

The fitted model for hill region implied that the log odds of favoring "modern" (crop types = " 1 or, modern") compared to "traditional" crop ("0 or, traditional") was predicted by the three independent variables, plot size, distance and family size of sample districts in Central Development Region. The variables plot size and distances had positive effects on log odds of crop whereas family size had negative effect on the log odds. From the fitted model it could be concluded that a unit hector change in plot size caused decrease in log odds of modern crops with compared to traditional crop by a factor of 7.51, holding other factors constant. A one unit change in distance decreased in log odds of modern crop when compared to traditional crop by a factor of 1.06 , holding other factors constant. Similarly, a person increase in a family caused an increase in log odds of modern crops when compared to traditional crops by a factor of 0.53 , holding other factors constant.

Now interpreting the odds ratio, $\operatorname{Exp}(b)$ from Table 2, odds ratio, 0.0005 of plot size implied that the model predicted odds of favoring "modern" crops compared to "traditional" crops (i.e. opposing modern crops) were decreased by a factor of 0.0005 per ha change in plot size, holding other variables constant. The factor was very low though it seemed significant (Table 2).
Comparing the next factor distance with dependent variable crop types, the model predicted odds of favoring "modern" crops compared to opposing it (i.e. favoring traditional crops) were decreased by a unit of 0.35 for unit $\mathrm{km}$ change in distance, holding other variables constant. Similarly, the next factor family size compared with the dependent variable, the model predicted odds of favoring "modern" crops compared to "traditional" crops were increased by a factor of 1.70 for each person increased in the family, holding other variables constant. In other words, addition of one member in a family increased odds of favoring "modern" compared to "traditional" crops by 70 percent, keeping effects of other variables remaining the same.

\section{Effects of Factors on Cropping Patterns in the Plains}

As in hill region, same independent variables were entered in the logistic regression model. Four variables were removed on stepwise (forward Wald) logistic regression analysis and the three variables plot size $\left(\mathrm{x}_{1}\right)$, distance $\left(\mathrm{x}_{2}\right)$, profit $\left(\mathrm{x}_{4}\right)$ and market $\left(\mathrm{x}_{7}\right)$ were remained significant, and family size $\left(\mathrm{x}_{3}\right)$ and education $\left(\mathrm{x}_{6}\right)$ were not accepted by the model. Descriptive statistics of the variables under consideration in the plain (Terai) region have been presented in Table 4 .

Table 4. Descriptive statistics of the variables for Terai region

\begin{tabular}{l|l|l|l|l|c}
\hline & $\mathrm{N}$ & Minimum & Maximum & Mean & Variance \\
\hline Crop variety(y) & 102 & 0.000 & 1.000 & & \\
Plot size (x1) & 102 & 0.050 & 2.000 & 0.607 & 0.155 \\
Distance (x2) & 102 & 0.200 & 7.000 & 2.645 & 4.235 \\
Irrigation(x3) & 102 & 0.000 & 1.700 & 0.289 & 0.122 \\
Profit (x4) & 102 & 0.000 & 1.000 & & \\
Family size(x5) & 102 & 2.000 & 12.000 & 5.780 & 4.507 \\
Total N & 102 & & & & \\
\hline
\end{tabular}


The model fitted well with insignificant $(\mathrm{p}=0.99)$ Hosmer and Lemeshow (SPSS 1999) chi-square value of 1.632 with 8 degrees of freedom and Nagelkerke $\mathrm{R}^{2}$ value of 0.821 . There was no significant multicolinearity between the independent variables (Table 6). The estimated values of parameters ( $b$ 's) of the significant predictors have been presented in Table 5 .

Table 5. Estimated parameters with significant values of the model for Terai region

\begin{tabular}{|c|c|c|c|c|c|c|c|}
\hline & Predictors & $\mathrm{b}$ & S.E. & Wald Chi ${ }^{2}$ & $\mathrm{df}$ & Sig. & $\operatorname{Exp}(b)$ \\
\hline Step 4 & $\begin{array}{l}\text { Plot size }\left(\mathrm{x}_{1}\right) \\
\operatorname{Distance}\left(\mathrm{x}_{2}\right) \\
\text { Profit }\left(\mathrm{x}_{4}\right) \\
\operatorname{Market}\left(\mathrm{x}_{7}\right) \\
\operatorname{Market}(1)\left(\mathrm{x}_{7(1)}\right) \\
\operatorname{Market}(2)\left(\mathrm{x}_{7(2)}\right) \\
\text { Constant }\end{array}$ & $\begin{array}{l}-8.211 \\
-.658 \\
2.360 \\
\\
4.437 \\
2.892 \\
2.297\end{array}$ & $\begin{array}{l}2.342 \\
.240 \\
1.133 \\
\\
1.353 \\
1.168 \\
1.371\end{array}$ & $\begin{array}{l}12.295 \\
7.495 \\
4.342 \\
10.756 \\
10.750 \\
6.131 \\
2.804\end{array}$ & \begin{tabular}{l|l} 
& \\
1 & \\
1 & \\
2 & \\
1 & \\
1 & \\
1 &
\end{tabular} & $\begin{array}{l}.000 \\
.006 \\
.037 \\
.005 \\
.001 \\
.013 \\
.094\end{array}$ & \begin{tabular}{r}
\multicolumn{1}{c}{0003} \\
.518 \\
10.594 \\
\\
84.492 \\
18.022 \\
9.940
\end{tabular} \\
\hline
\end{tabular}

a Variable(s) entered on step 1: Market.(category), Market (1)=Good, Market (2)=So_So, Market (3)=Bad (as reference).

b Variable(s) entered on step 2: Plot size

c Variable(s) entered on step 3: Distance

d Variable(s) entered on step 4: Profit

From the results given in the Table 5, logistic regression model with following parameters was fitted for Terai region of Central Development Region.

where, $x_{1}=$ Plot size, $x_{2}=$ Distance and $x_{4}=$ Profit (dichotomous covariate), $x_{7}=$ Market (as category) with $\mathrm{x}_{7(1)}=\operatorname{Market}(1)=\operatorname{good}, \mathrm{x}_{7(2)}=\operatorname{Market}(2)=$ so-so (average), $x_{7(3)}=\operatorname{Market}(3)=$ bad (as reference). All the estimated parameters were seemed to be highly significant and their corresponding odds ratios are given in the last column of Table 5.There was no multicolinearity between the predictors (Table 6 ). The correlation coefficients between the independent variables entered in the model have been presented in Table 6.

Table 6. Correlation matrix

\begin{tabular}{l|l|c|c|l|l|l|l}
\hline \multicolumn{2}{l|}{} & Constant & Market(1) & Market(2) & Plot Size & Distance & Profit \\
\hline Step 4 & Constant & 1.000 & -.130 & -.261 & -.673 & -.536 & .336 \\
& Plot Size & -.673 & -.391 & -.286 & 1.000 & .308 & -.409 \\
& Distance & -.536 & -.197 & -.198 & .308 & 1.000 & -.048 \\
& Profit & .336 & -.096 & -.049 & -.409 & -.048 & 1.000 \\
& Market(1) & -.130 & 1.000 & .539 & -.391 & -.197 & -.096 \\
& Market(2) & -.261 & .539 & 1.000 & -.286 & -.198 & -.049 \\
\hline
\end{tabular}

Note: VIF is around 1 in all cases.

By fitting of the model one could interpret the results as: in Terai region, a unit hector change in plot size would decrease 8.21 times the log odds of favoring "modern" crop compared to "traditional" crop, holding other variables constant. A unit $\mathrm{km}$ change in distance would decrease 0.658 times the log odds of modern crop compared to traditional crop, holding other variables constant. Profit factor would change the log odds of modern crop compared to traditional crop by a unit of 2.36 , holding other variables constant. That is, if profit was changed from 0 to $1(1=$ yes, $0=$ no $)$, the log odds of choosing modern crop would change by 2.36 times than that of choosing traditional crop, holding other variables constant. Market was the highly significant factor in Terai as it is shown in the Table 5. Market (1) and market(2) were also highly significant in the model. They had affected the log odds of crop-types by 4.44 and 2.89 times respectively, holding other variables constant. 
Raj Man Shrestha /Factors Affecting the.....

Now again, odds ratios, $\operatorname{Exp}(\mathrm{b})$ of different parameters could be interpreted as follows: in Terai region (Table 5) the odds of favoring modern crops compared to traditional crops were decreased by a unit of 0.0003 for one ha change in plot size, holding other variables constant. The odds of favoring modern crops compared to traditional crops were decreased by a unit of 0.518 for one $\mathrm{km}$ change in distance (from the market to the cropping land), holding other variables constant. The odds of favoring modern crops compared to opposing it (favoring traditional crops) were increased by a unit of 10.59 for the change in profit from " 0 or, no" to " 1 or, yes". In other word, the odds of favoring modern crops compared to traditional crops would be 10.594 times greater if profit option was chosen to "yes" rather than to choose "no". The odds of favoring modern crops compared to opposing it (favoring traditional crops) were increased by a unit of 84.49 for the change in market situation to"good" from "bad". In other words, the odds of favoring modern crops compared to traditional crops would be 84.49 times greater if the situation of market changed from "bad" to "good" situation. Similarly, the odds of favoring modern crops compared to opposing it (favoring traditional crops) were increased by a unit of 18.022 for the change in market situation to "so-so" from "bad". In other words, the odds of favoring modern crops compared to traditional crops would be 18.022 times greater if the market changed from "bad" to "so so" situation. Note that the third category of market i.e. "bad" situation of market was considered as reference.

Results obtained from the above analysis showed that there existed non-linear relationships between dependent variable (types of crops) and independent variables (factors) at both the regions of the Central Development Region. In hill region, the decision taken by the farmers on crops was affected by the factors, viz size of the plot, distance from the market place and the family size. Greater the distance from the market place, the farmers gave less priority to the modern crops and gave high priority to the traditional crops and vice-versa. Similarly, the size of plot also affected the decision in reverse way i.e. the farmers holding a large plot size preferred the traditional while crops and the farmers holding a small plot size preferred the modern crops. The next factor family size had the positive effect on the decision. The farmers with a large family size preferred the modern crops and the farmers with a small family size preferred the traditional crops.
In Terai region, the decision taken by the farmers on crops was affected by the factors, viz size of plot, distance from the market place, profit from crops and the market facilities. As in hills, plot size and distance factors had negative impacts on choosing the modern crops in their fields. Other factors (profit and market facilities) had positive impacts on choosing modern crops in their fields. Due to high profit as well as market facilities the farmers preferred modern crops rather than the traditional crops in their fields.

It can be concluded that the factors affecting the change in cropping patterns in hills and Terai regions are plot size, distance, family size, profit from the crop, and market opportunities. The variables education and irrigation are not the significant factors for changing the cropping patterns in hills and Terai regions. The variables plot size and distances have negative effect on change in cropping patterns from modern to traditional crops. Profit is the main significant factor of change in crop in Terai whereas family size is the significant factor of change in hill region of the Central Development Region.

\section{Acknowledgement}

I would like to acknowledge Professor M.L. Singh, Sanepa, Lalitpur, for his encouragement and help in preparing this paper. I am also grateful to Professor Fanindra Neupane, Academician, NAST, Khumaltar, Lalitpur, for his valuable suggestions in completing this paper.

\section{References}

Shrestha, R.M. 2006. Urbanization and changes in cropping patterns at Kathmandu vally. Nepal Journal of Science and Technology 7:113-117.

CBS. 2001. Population census. (National report). Central Bureau of Statistics, Kathmandu, Nepal.

Garson, G.D. 2009. Logistic regression. www.logistic $\mathrm{R} \backslash$ Logistic Regression Statnotes, from North Carolina State University, Public Administration Program.htm

Cochran, W.G. 1977. Sampling Techniques. (2nd edition), Willy Eastern Limited, New Delhi.

Mathema, S.B. and M.G. Van Der Veen. 1978. Key informant survey at Ratna Nagar Panchayat. Cropping Systems Programme, Agronomi Division, Department of Agriculture, Ministry of Agriculture, HMG, Nepal. pp 12-14.

Ranjit, N.G. 1983. Change in agriculture land use and land value in urban fringe of Kathmandu city. Ph.D thesis, Tribhuvan University, Kathmandu, Nepal.

SPSS. 1999. SPSS Base 9.0 Application Guide. SPSS Inc., Chicago, USA 
Nepal Journal of Science and Technology 10 (2009) 